\title{
INFORMATION SYSTEMS OUTSOURCING SATISFACTION: SOME EXPLANATORY FACTORS
}

\section{PAPER TYPE Research Paper}

\section{ABSTRACT}

Purpose- The present study analyses IS outsourcing success, measuring the latter according to the satisfaction level achieved by users and taking into account three success factors: the role played by the client firm's top management; the relationships between client and provider; and the degree of outsourcing.

Design/methodology/approach- A survey was carried out by means of a questionnaire answered by 398 large Spanish firms. Its results were examined using the PLS software and through the proposal of a Structural Equation Model (SEM).

Findings- The conclusions reveal that the perceived benefits play a mediating role in outsourcing satisfaction and also that these benefits can be grouped together into three categories: strategic; economic; and technological ones.

Originality/Value- The study identifies how some success factors will be more influential than others depending on what type of benefits are ultimately sought with outsourcing.

Keywords- Outsourcing, Information Systems, success, satisfaction, perceived benefits, SEM 


\section{INFORMATION SYSTEMS OUTSOURCING SATISFACTION: SOME EXPLANATORY FACTORS ${ }^{1}$}

\section{INTRODUCTION}

The trend towards the outsourcing of various firm processes has kept increasing throughout the world's developed economies during the last few years (Kim, Lee, Koo \& Nam, 2013). This process has occurred most visibly in the Information Systems/Information Technologies (IS/IT) area. Although IS outsourcing has had to coexist in recent years with Backsourcing - the process of recalling operations 'back inhouse' after they have been outsourced (Bhagwatwar, Hackney \& Desouza, 2011; SolliSæther \& Gottschall, 2015) - especially due to the financial and economic crisis originated in 2008 (Kotlarsky \& Bognar, 2012), the truth is that IS outsourcing came to stay.

IS outsourcing has consequently become consolidated as a usual practice in today's firms (Qi \& Chau, 2013). According to Computer Economics (2014), IT outsourcing budgets represented a $10.2 \%$ of the total IT budget in 2014, and some IT activities, such as Application Development, have been outsourced entirely or partly by $61 \%$ of organizations. However, despite the ever-growing trend towards outsourcing, few organisations openly declare to have achieved success with outsourcing (Huber, Fisher, Kirsch \& Dibbern, 2014).

From the academic sphere, there has been a proliferation of studies which try to explain the influence exerted by diverse factors on outsourcing success. For instance, the work of Marchewka \& Oruganti (2013) introduced process- and culture-related factors as new determinants of outsourcing success. In turn, Cetinkaya, Ergul \& Uysal (2014) dealt with the influence that relationship quality has on outsourcing success. The paper by Lee (2001) referred to the impact of knowledge sharing, organizational capacity and outsourcing relationship quality on outsourcing success. Kim and Chung (2003) observed the influence exerted by the tasks to be outsourced as well as the relationship features on outsourcing success. And finally, Rustagi, King \& Kirsch (2008) studied the characteristics of client control over the vendor as a critical outsourcing success factor. Despite all these studies,

\footnotetext{
${ }^{1}$ The authors would like to express their gratitude to the editor and the three anonymous reviewers for all their helpful suggestions.
} 
the literature has not given much clear advice about the keys to IS outsourcing success (Seddon, Cullen \& Willcocks, 2007).

Along these research lines, the present paper seeks to study the factors which have some bearing on IS outsourcing success, with a special focus on three of them: relationship with providers; degree of outsourcing; and support given by the top management. Our attention centres upon the mediating role of perceived benefits and their influence on users' satisfaction. The novelty of our approach lies in considering customer satisfaction as a final and comprehensive measure of outsourcing success. Hence our definition of satisfaction as a second-order construct explained by the perceived benefits of outsourcing -which are first-order constructs.

Our paper is based on the results of a survey carried out among the IS executives of the largest Spanish firms. After an initial literature review which serves as the foundation for deducing the hypotheses to be verified, the results and conclusions obtained will be presented through the implementation of a structural equation model.

\section{LITERATURE REVIEW}

IS outsourcing refers to the practice of shifting one or more organizational IT-related activities to an outside firm (Schwarz, 2014). As global supply markets have continued to increase, businesses now have the opportunity to reassess which IT functions should remain in-house and which could be outsourced (Marchewka \& Oruganti, 2013). However, although the IT outsourcing phenomenon has been expanding during the last decade, the outsourcing success rate remains low (Kim, Lee, Koo \& Nam, 2013). This justifies our decision to perform a literature review about IS outsourcing success factors and how to measure IS outsourcing success.

\subsection{Success factors}

Many factors have been identified as determinants of IS outsourcing success; amongst them stand out factors referring to the firm's external relationships with the client firm such as: communication and collaboration between client and provider (Han, Lee \& Seo, 2008); relationship with providers (Koh, Ang \& Straub, 2004); and knowledge transfer between provider and client (Koh, Ang \& Straub, 2004). Other factors are markedly internal, namely: support offered by the client firm's Top Management (Väyrynen \& Kinnula, 2012); correct definition of clients' needs (Gottschalk \& Solli-Sæther, 2005); or 
clients' supervision of the work carried out by their providers (Kim \& Chung, 2003). A mention can also be made of factors related to how outsourcing is approached, including type of contract (Burdon \& Bhalla, 2005) or degree of outsourcing (Grover, Cheon \& Teng, 1996).

Amongst all the factors listed above, our focus in the present work will be placed on analysing the role played by an external factor (relationship with providers) and another one internal to the client firm (Top Management's role), together with a factor linked to the actual outsourcing practice (degree of outsourcing).

\subsubsection{Relationship with providers}

IS outsourcing success requires a careful management of client-provider relationships (Kern \& Willcocks, 2002; Koh, Ang \& Straub, 2004, Gottschalk \& Solli-Sæther, 2005). The contacts or relationships between both parties will make it possible to build work relationships based on trust and on a comfortable mutual treatment, which very often implies having to overcome certain problems and difficulties (Clark, Zmud \& McCray, 1995; Willcocks, Lacity \& Kern, 1999). These relationships may even result in alliance- or partnership-type agreements between client and provider (Judenberg, 1994; Lee, 2001).

A closer relationship with providers could simultaneously ensure the provider's acclimatisation to the client's style and culture. It must be remembered that managerial and cultural fit has proved to be an essential success factor in outsourcing relationships (Hurst \& Hanessian, 1995; Martinsons, 1993; McFarlan \& Nolan, 1995). It thus becomes essential to achieve a good level of communication between client and seller (Baldwin, Irani \& Love, 2001; Lee \& Kim, 1999; Han, Lee \& Seo, 2008), along with relationship continuity. Outsourcing contract conditions may evolve over time as its aims, technology, or the organization change; therefore, changes must be anticipated in order to guarantee a successful medium- and long-term relationship (Diromualdo \& Gurbaxani, 1998; Zhang, Zeng \& Huang, 2007).

Firms which achieve success in their outsourcing contracts do not merely establish a clientprovider relationship with their counterparts but also develop strong ties which coordinate both contract parties (Grover, Cheon \& Teng, 1996), ranging from the implementation of joint initiatives to relationships where the provider is a subsidiary or affiliate of the client firm -referred to as 'quasi-outsourcing' by various authors (Barthélemy \& Geyer, 2005; Väyrynen \& Kinnula, 2012). 
The previous lines of reasoning lead us to infer the following hypothesis:

H1: The closer the relationship with providers, the greater IS outsourcing success will be achieved.

\subsubsection{Degree of Outsourcing}

The degree of outsourcing represents the proportion of functions typical to the IS service being outsourced. With total insourcing, the organisation owns the whole IS infrastructure being responsible for delivering services to users. In the case of selective outsourcing, external providers complement IS internal capabilities. Even though the organisation has practically total control over IS services, it may outsource some activity to an external provider for specific IS areas (Gulla \& Gupta, 2012). As for total outsourcing, Lacity, Willcocks and Feeny (1996) claim that it occurs if the client spends over 80\% of its computer budget on IS outsourcing.

Selective IS outsourcing has been proposed as a better option than total insourcing or total outsourcing in IS outsourcing decisions (Lacity, Willcocks \& Feeny, 1996; Lee, Miranda \& Kim, 2004; Shi, 2010; Väyrynen \& Kinnula, 2012); in other words, it correlates positively with outsourcing success. However, without going as far as recommending total outsourcing, authors such as Grover, Cheon and Teng (1996) state that the degree of outsourcing correlates positively with the success level attained. Therefore, H2: The higher the degree of outsourcing, the greater IS outsourcing success will be achieved.

\subsubsection{Top Management's Role}

The top management's involvement in IT-related decisions has repeatedly appeared as a determining factor for good or bad IS department performances (Jarvenpaa \& Ives, 1991; Kanter, 1992; Rockart, Earl \& Ross, 1996; Yap, Soh \& Raman, 1992). For the same reason, the support given by the top management also proves crucial for the IS outsourcing process (Zviran, Ahituv \& Armoni, 2001; Fjermestad \& Saitta, 2005; Burdon \& Bhalla; 2005). Thus, a joint involvement of the firm's top management and the IS executives must exist in any IS outsourcing decision -though each group assumes a different role (Lacity, Hirschheim \& Willcocks, 1994). On the one side, the top management needs to identify both business-related and technical objectives, defining the scope for outsourcing 
assessment, developing criteria to analyse the offers received and, finally, verifying that offer analysis. On the other side, the IS management plays a critical role, since it has to create a detailed request for quotation (RFQ) to evaluate the chances for the provider to obtain economies of scale, to estimate the effects of improvements on price and performance, and to offer ideas about emergent technologies which can affect the business. The following hypothesis can consequently be posed:

H3: A stronger role of the Top Management in IS will determine a greater level of success in IS outsourcing.

\subsection{IS outsourcing success: How to measure it}

Defining and measuring IS outsourcing success is far from easy (Schwarz, 2014). Nevertheless, from an academic perspective, different authors have suggested measuring the degree of outsourcing success as the sum of two factors: Benefits Perceived with outsourcing; and Overall Satisfaction reached therewith (Grover, Cheon \& Teng, 1996; Kim \& Chung, 2003; Saunders, Gebelt \& Hu, 1997; Han, Lee \& Seo, 2008; Seddon, Cullen \& Willcocks, 2007).

\subsubsection{Benefits Perceived with Outsourcing}

As for perceived benefits, they refer to the client's perception about the advantages obtained through outsourcing. Since those benefits are also the reasons underlying any outsourcing contract or, expressed differently, the client's expectations with regard to it, those perceived benefits measure the extent to which the aforesaid expectations have been met from the client's point of view (Kim \& Chung, 2003).

The literature review performed by Gonzalez, Gasco and Llopis (2010a) enables us to propose the following IS outsourcing reasons or expectations:

Increasing flexibility; Getting rid of routine tasks; Focusing on strategic tasks; Improving quality; Having alternatives to the internal IS; Reducing the risk of obsolescence; Facilitating access to technology; Saving Staff costs; and Saving technology costs.

The aforelisted reasons were already verified in previous empirical studies which made it possible to reduce and summarise the benefits perceived through outsourcing into three groups: economic; technological; and strategic (Saunders, Gebelt \& Hu, 1997; Rustagi, 
King \& Kirsch, 2008; Han, Lee and Seo, 2008; Kim and Chung, 2003; Grover, Cheon and Teng, 1996) (see ANNEX).

Taking up hypotheses 1, 2 and 3 again, it can be stated that, since perceived benefits are necessary for outsourcing success, there must be a positive relationship between the closer link with providers and perceived benefits; the higher degree of outsourcing and perceived benefits; and, finally, the stronger top management's role in IS and perceived benefits. Hypotheses 1, 2 and 3 can consequently be subdivided into the following sub-hypotheses (see Figure 1, part a):

H1a: The closer the relationship with providers, the greater the economic benefits perceived with IS outsourcing success.

H1b: The closer the relationship with providers, the greater the technological benefits perceived with IS outsourcing success.

H1c: The closer the relationship with providers, the greater the strategic benefits perceived with IS outsourcing success.

H2a: The higher the degree of outsourcing, the greater the economic benefits perceived with IS outsourcing.

H2b: The higher the degree of outsourcing, the greater the technological benefits perceived with IS outsourcing.

H2c: The higher the degree of outsourcing, the greater the strategic benefits perceived with IS outsourcing.

H3a: A stronger Top Management's role in IS entails greater economic benefits perceived with IS outsourcing.

H3b: A stronger Top Management's role in IS entails greater technological benefits perceived with IS outsourcing.

H3c: A stronger Top Management's role in IS entails greater strategic benefits perceived with IS outsourcing.

\section{INSERT FIGURE 1}

\subsubsection{Satisfaction}

As for satisfaction, a number of authors have suggested that satisfaction alone is a good measure of success (Kim, Lee, Koo \& Nam, 2013; Yoon \& Im, 2005, Song \& Wong, 2009). The reason may be twofold (Seddon, Cullen \& Willcocks, 2007): firstly, it means including and tacitly gauging the costs and benefits implicit in outsourcing; and secondly, 
satisfaction always constitutes a valid measure, unlike other more specific measures which are not suited to all cases. For instance, controlling costs, obtaining economies of scale or gaining access to cutting-edge technology usually arise as reasons for outsourcing; nevertheless, these may not be the aims sought through outsourcing in some specific firms. Any firm wishes to be satisfied with this service, though.

Following this approach, success could be measured in two steps: the first one through the strategic, technologic or economic perceived benefits that outsourcing achieves. This is an intermediate measure of outsourcing success which does not represent a valid or definitive measure for every firm, since firms do not necessarily have to seek these three types of benefit at the same time. Nevertheless, reaching these benefits (whether they are strategic, technological and/or economics) will undoubtedly influence the satisfaction reached by the client with outsourcing (Kim, Lee, Koo \& Nam, 2013; Viviek, Richey \& Vivek, 2009). Therefore, satisfaction does constitute a final measure -valid for any firm- of the success achieved through outsourcing. This is where Hypothesis 4 -which could also be divided into sub-hypotheses $4 \mathrm{a}, 4 \mathrm{~b}$ and $4 \mathrm{c}$ (see Figure 1, part b)- derives from:

H4: The more perceived benefits the higher satisfaction obtained with outsourcing. H4a: The more economic benefits the higher satisfaction obtained with outsourcing. H4b: The more technological benefits the higher satisfaction obtained with outsourcing. H4c: The more strategic benefits the higher satisfaction obtained with outsourcing.

\section{METHODOLOGY}

\subsection{Population and sample}

The directory Las 5.000 Mayores Empresas [The largest 5,000 companies] of the magazine Actualidad Económica [Economic Current News] was used to determine the study population, collating it with Duns and Bradstreet's database 50.000 Principales empresas Españolas [The main 50,000 Spanish companies]. A total of 45 companies were discarded among the 5,000 companies with the highest turnover from the first database because their address and telephone number coincided with those of other firms, which suggested that they were subsidiaries of the former.

The remaining 4,955 companies received a questionnaire in two formats, first electronic and then in paper; follow-up calls were made too.

The survey addressee was the IS manager of each company, like in other outsourcing studies (Shi, 2010). The information obtained was subsequently elaborated upon using the 
SPSS and Smart PLS statistical software programs. SPSS was used for univariate and bivariate analyses, and hypotheses were tested using a Structural Equation Model (SEM), with the PLS (partial least squares) technique. This technique has proved useful when it comes to analysing in a single step the measurement model that relates a latent variable to its items or observed variables, with the structural model that relates constructs or latent variables to one another. Furthermore, the PLS technique has amongst its advantages that it does not require uniformity in measuring scales (Sosik, Kahai \& Piovoso, 2009) and can combine reflective and formative measures without any identification problems whatsoever (Chin, 2010).

\section{INSERT TABLE 1}

Table 1 shows the study technical specifications. A total of 398 valid responses collected between October 2012 and February 2013 was obtained (representing 8\% of the population examined). This ratio is similar to the ones found in other studies (Bahli \& Rivard, 2005; Ma, Pearson \& Tadisina, 2005; Shi, Kunnathur \& Ragu-Nathan, 2005). The profile of companies which answered this survey is representative of the overall population ${ }^{2}$.

\subsection{Measurement of variables}

The variable measurement carried out was based on a review of previous questionnaires and works about IS outsourcing. More specifically, the degree of outsourcing was measured using a scale proposed by Gonzalez, Gasco and Llopis (2008) with interviewees being asked to determine the approximate percentage in which an extensive list of activities referring to IS are outsourced on a 1 -to- 5 Likert scale -1 meaning below $20 \%$ and 5 , above $80 \%$. The 1-to-7 Likert scale, the most commonly preferred one in the context of social sciences, is better than the 1-to-5 scale because measuring sensibility increases and one can have more guarantees that a continuous variable -instead of a categorical one- is being used; hence our decision to utilise it in the survey. Nevertheless, the variable 'degree of outsourcing' is measured with a 1 -to-5 scale due to the fact that interviewees find it hard to convert outsourcing percentages into scores.

\footnotetext{
2 Readers could request the statistical analyses.
} 
As for 'Relationship with Providers,' it was equally measured through a scale adapted from Gonzalez, Gasco \& Llopis (2008), where interviewees had to assess between 1 and 7 whether certain proximity and agreement relationships with providers never occur (1) or such relationships are established in all cases (7).

With regard to 'Top Management's Role' in the IS context, a decision was made to adopt a scale elaborated by us and based on the contributions made by Arnett and Jones (1994), Baldwin, Irani \& Love (2001), and Lacity \& Willcockcs, 1998), where interviewees assessed their level of involvement with business IS vision, use and decision-making from 1 (little, low) to 7 (a lot, high).

The three preceding variables were measures with formative scales (Becker; Klein \& Wetzels, 2012), insofar as the items shaping each variable exert a joint influence on the variables, that is, the indicators are causes or determinants of variables.

The Strategic, Technological and Economic Benefits perceived with outsourcing, as well as the satisfaction obtained with it were measured taking as a reference the study written by Gonzalez, Gasco \& Llopis (2010b), which in turn was based on the works of Grover, Cheon and Teng (1996), Gupta and Gupta (1992), and Saunders, Gebelt \& Hu (1997). These variables were measured with reflective scales because the indicators shaping them are a reflection or expression of the variables that they represent. All the measurements can be seen in more detail in the Annex.

\section{Results}

Let us see some descriptive survey results before analysing the theoretical model outcomes.

\subsection{Descriptive Results}

Only 54 firms (13.6\% of the population) do not perform any type of IS outsourcing. Figure 2 offers the percentages of outsourcing for different IS activities -represented by stretches from 1 to 5 (see Annex). The mean outsourcing percentage for the different activities is below $50 \%$ on average, except for hardware maintenance, programming, systems installation and software maintenance. This shows that firms carry out a selective type of outsourcing (see Figure 2). It deserves to be highlighted that the 4 most often outsourced activities in 2013 are the same as those identified in the previous study of Gonzalez, Gasco \& Llopis (2008).

INSERT FIGURE 2 
Concerning relationship with providers, Top Management's role in IS decisions, perceived benefits and satisfaction with outsourcing, the descriptive results (means of items) can be seen in Figure 3 (remember that a 1-to-7 scale was used for these items). Relationships with providers are not too close but the Top Management's in IS decisions is indeed strong, since all items exceed the mean. As for benefits, the same Figure 3 shows that those of a strategic nature are perceived to a greater extent than technological ones and, finally, than economic ones. As for the satisfaction level at the interviewed firms, it is quite high.

INSERT FIGURE 3

\subsection{Measuring Model}

Our next concern will be the validity both of reflective and formative measures and of the structural model itself.

\subsection{Validity of reflective measures}

Seeking to analyse reflective measures with the PLS technique, an analysis is performed about each item's individual reliability, the construct's reliability or internal consistency, and convergent and discriminant validity (Fornell \& Larcker, 1981; Tenenhaus et al., 2005).

\section{INSERT TABLE 2}

Item's individual reliability. Factor loadings of indicators are assessed in this section, and those indicators with loadings above 0.707 must be retained. Should loadings be situated in values between 0.4 and 0.707 , it would be necessary to examine the AVE (Average Variance Extracted). It can be checked that all loadings -save for Stra.B4 and Stra.B5- are above the accepted limit (see Table 2). Anyway, the values of these two indicators are very high, close to 0.707 , which discouraged us from eliminating them. Convergent validity must be borne in mind too because, if AVE exceeds 0.5, it is understood that constructs are valid and consequently count on correct indicators.

Construct's reliability, or internal consistency, serves to determine how rigorously the same latent variable is expressed by indicators, for which purpose Cronbach's $\alpha$ and composite reliability are analysed. In any case, both values exceed the 0.7 barrier established by Nunnally (1978). 
Convergent Validity implies that a set of indicators represents a single construct; the AVE value -which must be higher than 0.5 (Fornell \& Larcker, 1981)- is observed for this purpose.

Discriminant validity indicates the extent to which a given construct differs from other constructs. Gefen and Straub (2005) point out that it can be measured with two methods: firstly, through correlations between constructs and indicators. In this sense, reflective constructs were seen to have discriminant validity because the correlations with their indicators are higher than those with the remaining constructs. Secondly, the square root of average variance extracted for each latent variable has to be higher than the correlations between each construct and the other reflective constructs. This is visible in the bottom part of Table 3 which shows -on a diagonal and highlighted in bold- the square root of each construct's AVE, whereas the remaining values correspond to correlations between constructs.

\section{INSERT TABLE 3}

\subsection{Validity of formative measures}

The traditional evaluation of reliability and validity cannot be applied to formative measures (Bagozzi, 1994). Unlike what happens in reflective indicators, excessive collinearity is likely to destabilise the model in formative ones. For that reason, a number of authors recommend using the Variance Inflation Factor (VIF) in order to ensure that no multicollinearity exists (Diamantopoulos, Reynolds \& Simintiras (2006). If the VIF is lower than 3.3, there is no multicollinearity (Petter, Straub \& Rai, 2007).

As for the 'Degree of Outsourcing' Construct, it initially had eleven indicators. Removing one of them -hardware maintenance- permits to guarantee that no VIF is above 3.3 (see Table 4). Moreover, the condition index for all indicators is situated below 30 -the highest one being 12.587- which stresses the absence of multicollinearity. The other two formative constructs present no multicollinearity problems whatsoever.

INSERT TABLE 4

\subsection{Structural model analysis}

INSERT TABLE 5

The Bootstrapping technique (5,000 resamples) is used to calculate the $\mathrm{t}$ statistic which measures the significance corresponding to this model's coefficients. Similarly, the variance 
explained is calculated for those coefficients revealed as significant through the previous test. It is thus verified that only 8 of the 12 hypotheses proposed could finally be accepted (Table 5).

An additional calculation is made of the $\mathrm{R}^{2}$ for each dependent variable and of the $\mathrm{Q}^{2}$ in Stone Geisser's test, which was found using the procedure known as Blindfolding. $\mathrm{R}^{2}$ values are low but, since they all exceed 0.1, and following the criterion established by Falk and Miller (1992), they permit to state that the model has predictive capacity. Furthermore, the fact that every $\mathrm{Q}^{2}$ is above zero confirms the proposed model's predictive relevance (Stone, 1974; Geisser, 1974).

Figure 4 represents the suggested model and compares it with a simplified version of the same model where the mediating effect of Perceived Benefits has been removed. It can be seen that the complete model's predictive power is higher than that of its simplified version. The influence exerted by perceived benefits consequently becomes essential when it comes to assessing IS outsourcing success.

\section{INSERT FIGURE 4}

\section{CONCLUSIONS}

The present paper has implications both from an academic point of view and in practical terms. From an academic perspective, it is observed how the perceived benefits of outsourcing can play a mediating role in the satisfaction derived from it and, therefore, in the degree of success perceived. Although this study has only dealt with three possible outsourcing success factors, all three of them have shown positive correlations with satisfaction -but those correlations become stronger when the perception of several intermediate benefits is firstly achieved.

It has additionally been checked that the benefits obtained through outsourcing can be clearly grouped together into three blocks: strategic; economic; and technological; and likewise that these three types of benefits are of paramount importance when it comes to outsourcing success -to users' satisfaction in this case.

In practical terms, although numerous works have tried to list the factors which determine IS outsourcing success (Swarz; 2014) -showing how those factors impact positively on the success level attained- the significant contribution made by this study lies in the attempt to stress the idea that some factors outweigh others depending on the type of benefits ultimately sought with outsourcing. 
The novelty of our conclusions lies in the fact that client satisfaction has been used as a final and comprehensive measure of outsourcing success (being a second-order construct), which is achieved through perceived benefits -which act as a first-order construct. In this sense, our approach resembles the one adopted by Kim, Lee, Koo and Nam (2013) but differs from that of Marchewka \& Oruganti (2013), who define partnership quality as a basic antecedent of outsourcing success, or the ones by Qi \& Chau (2013) and Schwarz (2014), for whom perceived benefits are an essential part of outsourcing success.

The importance corresponding both to the role played by the top management and to the relationships with providers has consequently been confirmed but, especially, the present paper allows us to conclude that a more relevant role will have to be played by providers or the top management depending on the aims sought through outsourcing. Thus, if the main objectives sought through outsourcing are of a strategic nature, the strongest emphasis will have to be placed on making sure that the client firm's top managers pay attention to this type of contract, since their role becomes essential in the adoption of IS-related decisions; and, moreover, that they use these technologies in their everyday tasks, and that they give support to the role of IT in the firm's strategic aims -all of which will effectively demonstrate the strategic approach that guides outsourcing in this case. A similar conclusion was mentioned by Burdon and Bhalla (2005). Instead, if the central goals sought are economic, it is the providers and the relationships with the latter that will establish as a priority to help the client firm achieve those goals. In the event that joint initiatives should be shared with providers or even if ownership relationships exist between providers and clients, it will be much easier to attain objectives of an economic type. These results are in keeping with those obtained by Duhamel, Gutierrez, Picazo \& Luna (2014).

Hence why many of the challenges which firms need to face to achieve success in their outsourcing relationships are the same as the ones mentioned by Lacity, Willcocks \& Rottman (2008), namely: how can providers' incentives be aligned with clients' needs?; and how can clients and providers sustain an enthusiasm for the creation of relationships that can prove long-lasting? The answer -according to these same authors- lies in establishing partnership links between clients and providers which do not survive merely for their longevity but for the continued decision to update them with innovative ideas.

A higher degree of outsourcing decisively influences both greater benefits perceived with it and clients' satisfaction. Therefore, without actually recommending total outsourcing, it cannot be denied that a high degree of outsourcing in IS functions is not at all undesirable but even beneficial to their clients. Perhaps, the maturity of contracts together with the 
experience accumulated by providers and clients has made this practice previously regarded as risky (Gonzalez, Gasco \& Llopis, 2010a) become increasingly controlled, allowing it to gain more and more supporters.

IS outsourcing constitutes a widespread trend in the large Spanish firms analysed in this study. Descriptive statistics have shown that the greater perceived benefits are the strategic ones, followed by the technological ones and, in last place, by those associated with economic aspects. This comes as no surprise because, as shown in Figure 3, top management's involvement outweighs proximity between providers and clients, which determines the type of perceived benefit that is given more importance.

To quote but a few examples of large Spanish firms that have made well-known IS outsourcing contracts, one can mention Aena, the company which manages Spanish airports. Aena resorted to Bull to enhance its IS in 2013 mainly for strategic reasons (Computing, 2013). In the financial sector, Banco Popular signed an agreement with IBM with the aim of making a digital transformation in its business in July 2014. Under this agreement, IBM will manage the bank's private cloud and achieve savings of approximately 150 million euros over its 10-year validity period (Techweek, 2014) -economic and technologic benefits combine in this case. Another example can be found in Cuatrecasas, a legal firm that uses IS outsourcing to serve more than 1,600 employees who work in several cities around the world. In fact, over the $40 \%$ of the IS department staff in this company are external (CIO, 2013) -with strategic benefits being achieved.

Amongst the limitations faced in this paper, it is worth highlighting that it measures success qualitatively -and not quantitatively- since it does so through clients' satisfaction. In our view, a need exists to explore not only this one but also other outsourcing success models, being able to compare economic and quantitative variables such as business performance, which can complement the present study. So far, most of the works dedicated to outsourcing success analysis have exclusively focused on perceived success (Koh, Ang \& Straub, 2004). Another possible limitation could stem from the fact that satisfaction was measured with a single item; however, the same happens in the paper by Kim, Lee, Koo \& Nam (2013), who term this item as Overall Satisfaction.

An effort should definitely be made to carry out more in-depth studies about the relationships examined in the present paper so as to ensure that our findings can be generalized. Nevertheless, it is our conviction that they suggest an important line of research because not all success factors will impact to the same extent on the different types of outsourcing benefits. 
It becomes necessary to continue studying other factors which also influence outsourcing, and to analyse what a 'successful contract' means from the perspective of providers.

\section{REFERENCES}

Arnett, K.P. \& Jones, M.C. (1994): "Firms that choose Outsourcing: a profile". Information \& Management. Vol. 26, No. 4, pp. 179-188.

Bagozzi, R.P. (1994): "Structural Equation Models in Marketing Research: Basic Principles". In Bagozzi, R.P. Principles of Marketing Research. Oxford. Blackwell.

Bahli, B. \& Rivard, S. (2005): "Validating Measures of Information Technology Outsourcing Risk Factors". Omega. Vol. 33, No. 2, pp. 175-187.

Baldwin, L.P.; Irani, Z. \& Love, P. (2001): "Outsourcing Information Systems: Drawing Lessons from a Banking Case Study". European Journal of Information Systems. Vol. 10, No. 1, pp. 5-24.

Barthélemy, J. \& Geyer, D. (2005): "An empirical investigation of IT outsourcing versus quasioutsourcing in France and Germany". Information \& Management. Vol. 42, No. 4, pp. 533-542.

Becker, J-M.; Klein, K. \& Wetzels, M. (2012). "Hierarchical Latent Variable Models in PLS-SEM: Guidelines for using Reflective-Formative Type Models". Long Range Planning. Vol. 45, No. 5-6, pp. 359-394.

Bhagwatwar, A.; Hackey, R. \& Desouza, K.C. (2011): "Considerations for Information Systems "Backsourcing": a framework for knowledge Re-Integration". Information Systems Management. Vol. 28, No. 2, pp. 165-173.

Burdon, S. \& Bhalla, A. (2005): "Lessons from the Untold Success Story: Outsourcing Engineering and Facilities Management". European Management Journal. Vol. 23, No. 5, pp. 576-582.

Chin, W.W. (2010): "How to Write Up and Report PLS Analyses", in Esposito Vinzi, V., Chin, W.W., Henseler, J. \& Wang, H. (Eds.): Handbook of Partial Least Squares Springer Handbooks of Computational Statistics. Springer. pp. 655-690.

Cetinkaya, A.S.; Ergul, M. \& Uysal, M. (2014). "Quality relationship on information technology outsourcing for organizational success in hospitality industry". Journal of Hospitality and Tourism Technology. Vol. 5, No. 3, pp. 229-244.

CIO (2013). Cuatrecasas, Gonçalves Pereira, tecnología que aporta valor al negocio. Internet Document. http://www.ciospain.es/gobierno-ti/cuatrecasas-goncalves-pereira-tecnologia-queaporta-valor-al-negocio.

Clark, T.D.; Zmud, R.W. \& McCray, G.E. (1995): “The Outsourcing of Information Services: Transforming the Nature of Business in the Information Industry". Journal of Information Technology. Vol. 10, pp. 221-237.

Computer Economics (2014): “IT Outsourcing Statistics 2014/1015”. Computer Economics. Irvine.

Computing (2013). "Aena Aeropuertos opta por Bull para mejorar su sistema de gestión empresarial. Internet Document. http://www.computing.es/cios/noticias/1067594000201/aena-aeropuertos-opta-bullmejorar.1.html.

Diamantopoulos, A.; Reynolds, N.L. \& Simintiras, A.C. (2006): “The Impact of Response Style on the Stability of Cross-national Comparisons". Journal of Business Research. Vol. 59, No. 8, pp. 925-935.

Diromualdo, A. \& Gurbaxani, V. (1998): "Strategic Intent for IT Outsourcing". Sloan Management Review. Vol. 39, No. 4, 67-80.

Duhamel, F.; Gutierrez, I.; Picazo, S. \& Luna, L. (2014): "IT outsourcing in the public sector: a conceptual model". Transforming Government: People, Process and Policy. Vol. 8, No. 1, pp. 8-27.

Falk, R.F. \& Miller, N.B. (1992): “A Primer for Soft Modeling”. University of Akron Press. Akron. Ohio.

Fjermestad, J. \& Saitta, J.A. (2005): “A Strategic Management Framework for IT Outsourcing: A review of the Literature and the Development of a Success Factors Model". Journal of Information Technology Case and Application Research. Vol. 7, No. 3, pp. 42-60.

Fornell, C. \& Larcker, D.F. (1981): "Evaluating Structural Equation Models with Unobservable Variables and Measurement Error". Journal of Marketing Research. Vol. 18, No. 1, pp. 39-50. 
Gefen, D. \& Straub, D. (2005): “A practical guide to Factorial Validity using PLS-graph: Tutorial and Annotated Example". Communications of the Association for Information Systems. Vol. 16. Art. 5.

Geisser, S. (1974): “A Predictive Approach to the Random Effects Model”. Biometrika. Vol. 61, No. 1, pp. 101-107.

Gonzalez, R., Gasco, J. \& Llopis, J. (2008): “A descriptive analysis of IT outsourcing configuration". International Journal of Management and Enterprise Development. Vol. 5, No. 6, pp. 656-67211.

Gonzalez, R.; Gasco, J. \& Llopis, J. (2010a): "Information Systems Outsourcing Reasons and Risks: A New Assessment”. Industrial Management \& Data Systems. Vol. 110, No. 2, pp. 284-303.

Gonzalez, R.; Gasco, J. \& Llopis, J. (2010b): "Information Systems Outsourcing: An Empirical Study of Success Factors". Human Systems Management. Vol. 29, No. 3, pp. 139-151.

Gottschalk, P. \& Solli-Sæther, H. (2005): "Critical success Factors from IT outsourcing theories: an empirical study". Industrial Management \& Data Systems. Vol. 105, No. 6, pp. 685-702.

Grover, V.; Cheon, M.J. \& Teng, T.C. (1996): "The Effect of Service Quality and Partnership on the Outsourcing of Information Systems Functions". Journal of Management Information Systems. Vol. 12, No. 4, pp. 89-116.

Gulla, U. \& Gupta, M.P. (2012): "Deciding the level of Information Systems Outsourcing. Proposing a Framework and Validation with Three Indian Banks". Journal of Enterprise Information Management. Vol. 25, No. 1, pp. 28-59.

Gupta, G. \& Gupta, H. (1992): "Outsourcing the IS function. Is it necessary for your organization?” Information Systems Management. Vol. 9, No. 3, pp. 44-50.

Han, H-S.; Lee, J-N. \& Seo, Y-W. (2008): "Analyzing the impact of a firm's capability on outsourcing success; A process perspective". Information \& Management. Vol. 45, No. 1, pp. 31 42.

Hayes, D.C.; Hunton, J.E. \& Reck, J.J. (2000): "Information Systems Outsourcing Announcements: Investigating the Impact on the Market Value of Contract-Granting Firms". Journal of Information Systems. Vol. 14, No. 2, pp. 109-125.

Huber, T.L.; Fisher, T.A.; Kirsch, L. \& Dibbern, J. (2014): "Explaining Emergence and Consequences of Secific Formal Controls in IS Outsourcing: A process-View". 47th Hawaii International Conference in Information Systems.

Hurst, I. \& Hanessian, B.G. (1995): "Navigating IT Channels: Integrate or Outsource?", The McKinsey Quarterly. No. 3, pp. 103-110.

Jarvenpaa, S.L. \& Ives, B. (1991): "Executive Involvement and Participation in the Management of Information Technology". MIS Quarterly. Vol. 15, No. 2, pp. 205-227.

Judenberg, J. (1994): “Applications Maintenance Outsourcing. An Alternative to Total Outsourcing". Information Systems Management. Vol. 11, No. 4, pp. 34-38.

Kanter, J. (1992): "Information Literacy for the CEO". In Holtham, C. (ed.): "Executive Information Systems and Decision Support", pp. 17-28. Chapman and Hall. London.

Kern, T. \& Willcocks, L. (2002): "Exploring relationships in information technology outsourcing: the interaction approach". European Journal of Information Systems. Vol. 11, No. 1, pp. 3-19.

Kim, S. \& Chung, Y-S. (2003): "Critical Success Factors for IS Outsourcing Implementation from an Interorganizational Relationship Perspective". The Journal of Computer Information Systems. Vol. 43, No. 4, pp. 81-90.

Kim, Y.J.; Lee, J.M.; Koo, Ch. \& Nam, K. (2013): "The role of governance effectiveness in explaining IT outsourcing performance". International Journal of Information Management. Vol. 33. No. 5, pp. 850-860.

Koh, C.; Ang. S. \& Straub, D.W. (2004): "IT Outsourcing Success: a psychological Contract Perspective". Information Systems Research. Vol. 15, No. 4, pp. 356-373.

Kotlarsky, J. \& Bognar, L. (2012): "Understanding the process of backsourcing: two cases of process and product backsourcing in Europe". Journal of Information Technology Teaching Cases. Vol. 2. No. 2, pp. 79-86.

Lacity, M.; Hirschheim, R. \& Willcocks, L. (1994): "Realizing Outsourcing Expectations. Incredible Expectations, Credible Outcomes". Information Systems Management. Vol. 11, No. 4, pp. 7-18.

Lacity, M.C. \& Willcocks, L. (1998): "An empirical investigation of Information Technology Sourcing practices: lessons from experience”. MIS Quarterly. Vol. 22, No. 3, pp. 363-408. 
Lacity, M.C.; Willcocks, L. \& Feeny, D.F. (1996): “The Value of Selective Outsourcing”. Sloan Management Review. Vol. 37, No. 3, pp. 13-25.

Lacity, M., Willcocks, L. \& Rottman, J. (2008): "Global Outsourcing of Back Office Services: Lessons, Trends and Enduring Challenges". Strategic Outsourcing: An International Journal, Vol. 1, No. 1, pp 13-34.

Lee, J-N. (2001): “The Impact of Knowledge Sharing, Organizational Capability and Partnership Quality on IS Outsourcing Success". Information \& Management. Vol. 38, No. 5, pp. 323-335.

Lee, J-N. \& Kim, Y-G. (1999): "Effect of Partnership Quality on IS Outsourcing Success: Conceptual Framework and Empirical Validation". Journal of Management Information Systems. Vol. 15, No. 4, pp. 29-61.

Lee, J-N.; Miranda, S.M. \& Kim, Y-M. (2004): "IT Outsourcing Strategies: Universalistic, Contingency, and Configurational Explanations of Success". Information Systems Research. Vol. 15, No. 2, 110-131.

Ma, Q.; Pearson, J.M. \& Tadisina, S. (2005): “An Exploratory Study into Factors of Service Quality for Application Service Providers". Information \& Management. Vol. 42, No. 4, pp. 1067-1080.

Marchewka, J.T. \& Oruganti, S. (2013): "A combined model of IT Outsourcing Partnership and Success". Communications of the IIMA. Vol. 13, No. 2, pp. 69-85.

Martinsons, M.G. (1993): "Outsourcing Information Systems: A Strategic Partnership with Risk". Long Range Planning. Vol. 26, No. 3, pp. 18-25.

McFarlan, F.W. \& Nolan, R.L. (1995): "How to Manage an IT Outsourcing Alliance". Sloan Management Review. Vol. 36, No. 2, pp. 8-23.

Nunnally, J.C. (1978): "Psychometric Theory". Ed. McGraw-Hill. New York.

Petter, S.; Straub, D. \& Rai, A. (2007): "Specifying Formative Constructs in Information Systems Research”. MIS Quarterly. Vol. 31, No. 4, pp. 623-656.

Qi, C. \& Chau, P.Y.K. (2013): "Investigating the roles of interpersonal and interorganizational trust in IT outsourcing success". Information Technology \& People. Vol. 26. No. 2, pp. 120-145.

Roberts, N. \& Thatcher, J.B. (2009): "Conceptualizing and Testing Formative Constructs: Tutorial and Annotated Example". The DATA BASE for Advances in Information Systems. Vol. 40, No. 3, pp. 9-39.

Rockart, J.F., Earl, M.J. \& Ross, J.W. (1996): “Eight Imperatives for the New IT Organization”. Sloan Management Review. Vol. 38, No. 1, pp. 43-55.

Rustagi, S.; King, W.R. \& Kirsch, L.J. (2008): "Predictors of Formal Control usage in IT Outsourcing Partnerships". Information Systems Research. Vol. 19. No. 2, pp. 126-143.

Saunders, C., Gebelt, M. \& Hu, Q. (1997): "Achieving Success in Information Systems Outsourcing”. California Management Review. Vol. 39, No. 2, pp. 63-79.

Schwarz, C. (2014): "Toward an understanding of the nature and conceptualization of outsourcing success". Information \& Management. Vol. 51, No. 1, pp. 152-164.

Seddon, P.B.; Cullen, S. \& Willcocks, L.P. (2007): "Does Domberger's Theory of 'The Contracting Organization' explain Why Organizations Outsource IT and the Levels of Satisfaction Achieved?" European Journal of Information Systems. Vol. 16, No. 3, pp. 237-253.

Shi, Z. (2010): "The role of IS architecture planning in Enhancing IS Outsourcing's Impact on IS Performance: Its antecedents and an empirical test". Journal of Enterprise Information Management. Vol. 23, No. 4, pp. 439-465.

Shi, Z.; Kunnathur, A.S. \& Ragu-Nathan, T.S. (2005): "IS Outsourcing Management Competence Dimensions: Instrument Development and Relationship Exploration". Information \& Management, Vol. 42, No. 6, pp. 901-919.

Solli-Sæther, H. \& Gottschalk, P. (2015): "Stages-of-growth in outsourcing, offshoring and backsourcing: Back to the future?". The Journal of Computer Information Systems. Vol. 55, N. 2, pp. 88-94.

Song, H.M. \& Wong S.F. (2009): "Understanding Customer Satisfaction in the IT Outsourcing Environment: A Classification of Quality Attributes". Journal of Outsourcing and Organizational Information Management. Vo1, No.(4), 2009, pp. 27-31.

Sosik, J.J.; Kahai, S.S. \& Piovoso, M. J. (2009): "Silver Bullet or Voodoo Statistics? A Primer for using the Partial Least Squares Data Analytic Technique in Group and Organization research". Group \& Organization Management. Vol. 34, No. 1, pp. 5-36. 
Stone, M. (1974): "Cross-Validatory Choice and Assessment of Statistical Predictions". Journal of the Royal Statistical Society. Vol. 36, No. 2, pp. 111-147.

Techweek (2014). "Banco Popular e IBM firman un acuerdo estratégico de tecnologías de la información".

Internet

Document.

http://www.techweek.es/outsourcing/noticias/10140 81004401/banco-popular-ibm-firman-acuerdo.1.html.

Tenenhaus, M.; Vinzi, V.E. Chatelin, Y. \& Lauro, C. (2005): "PLS Path Modeling”, Computational Statistics \& Data Analysis. Vol. 48, No. 1, pp. 159-205.

Väyrynen, K. \& Kinnula, M. (2012): "Differences between success factors of IS quasi-outsourcing and conventional outsourcing collaboration: a case study of two Finnish companies". Electronic Markets. Vol. 22, No. 1, pp. 49-61.

Viviek, S.D.; Richey, R.G. \& Vivek, D. (2009): “A longitudinal examination of partnership governance in offshoring: A moving target". Journal of World Business. Vol. 44, No. 1, pp. 16-30.

Willcocks, L.P.; Lacity, M.C. \& Kern, T. (1999): "Risk mitigation in IT outsourcing strategy revisited: longitudinal case research at LISA". The Journal of Strategic Information Systems. Vol. 8, No. 3, pp. 285-314.

Yap, C., Soh, C. \& Raman, K. (1992): "Information Systems Success Factors in Small Business". OMEGA, Vol. 20, No. 5/6, pp. 597-609.

Yoon, YK. \& Im, K.S. (2005): "An Evaluation System for IT Outsourcing Customer Satisfaction Using the Analytic Hierarchy Process". Journal of Global Information Management. Vol. 13, No. 4, pp. 55-78.

Zhang, P.; Zeng, Z-X. \& Huang, C.P. (2007): "Study of Critical Success Factors for IT Outsourcing Lifecycle". 2007 International Conference on Wireless Communications, Networking and Mobile Computing WiCOM 2007. IEEE Communications Society, pp. 4379-4382.

Zviran, M., Ahituv, N. \& Armoni, A. (2001): "Building Outsourcing Relationships across the Global Community: the UPS-Motorola Experience". Journal of Strategic Information Systems. Vol. 10, No. 4, pp. 313-333. 
ANNEX. Description of the items used

\section{Degree of Outsourcing}

Assess from 1 to 5 the approximate percentage of the following activities which is outsourced, 1 meaning 'zero or very small, below 20\%' and 5 'very high, above $80 \%$.'

1. Degree1. Applications analysis

2. Degree2. Support to end users

3. Degree3. Staff training

4. Degree4. Systems installation

5. Degree5. Hardware maintenance

6. Degree6. Software maintenance
7. Degree7. Systems operation

8. Degree8. Programming

9. Degree9. Computer security

10. Degree10. Network service

11. Degree11. E-business solutions

\section{Relationship with Providers}

Assess from 1 to 7 the predominant relationship with providers of outsourced activities, 1 meaning 'this relationship never occurs' and 7, 'this relationship is established in all cases.'

1. Prov1. We do not share the ownership but we do share joint initiatives (such as marketing, R\&D\&I, etc.).

2. Prov2. Our firm owns part of providers' social capital.

3. Prov3. The providers are an affiliate or subsidiary of our firm.

\section{Top Management's Role}

Assess from 1 to 7 the role played by the Top Management with regard to IS/IT, 1 being 'neutral or hardly important' and 7, 'highly important.'

1. TM1. Importance allocated by the firm's top management to IS when it comes to fulfilling its business aims

2. TM2. Extent to which the top management uses IS in their everyday tasks

3. TM3. Role performed by the top management in the adoption of decisions about IS outsourcing

\section{Perceived benefits and Satisfaction}

Assess from 1 to 7 if success has been achieved with the outsourced activities, 1 meaning 'it has not been achieved at all' and 7, 'it has been totally achieved.'

\section{Strategic Benefits}

1. Stra.B1. Increasing IS department's flexibility

2. Stra.B2. Getting rid of routine and problematic tasks

3. Stra.B3. Being able to focus on the most strategic issues associated with IS

4. Stra.B4. Improving quality in the service offered

5. Stra.B5. Having alternatives to internal IS

\section{Technological Benefits}

1. Tec.B1. Reducing the risk of technological obsolescence

2. Tec.B2. Facilitating access to new technology

\section{Economic Benefits}

1. Eco.B1. Saving staff costs

2. Eco.B2. Saving technological costs

\section{Satisfaction}

1. Satis. Being satisfied with outsourcing in general 
Table 1: Study Technical Specifications

\begin{tabular}{|l|r|}
\hline & 2013 \\
\hline Scope & Spain \\
Population & 4,955 largest Spanish firms \\
Sample size & 398 valid answers (8.03\%) \\
Sampling error & $4.7 \%$ \\
Survey Date & October 2012-February 2013 \\
\hline
\end{tabular}

Table 2: Factor Loadings, Reliability and Convergent Validity

\begin{tabular}{|l|r|r|r|r|}
\hline & $\begin{array}{c}\text { Factor } \\
\text { loadings }\end{array}$ & Cronbach's $\alpha$ & $\begin{array}{l}\text { Composite } \\
\text { Reliability }\end{array}$ & AVE \\
\hline Economic Benefits & & 0.7168 & 0.8754 & 0.7785 \\
\hline Eco.B1 & 0.8643 & & & \\
\hline Eco.B2 & 0.9000 & & & \\
\hline Technological Benefits & & 0.8164 & 0.9134 & 0.8408 \\
\hline Tec.B1 & 0.8863 & & & \\
\hline Tec.B2 & 0.9466 & & & \\
\hline Strategic Benefits & & 0.7533 & 0.8337 & 0.5029 \\
\hline Stra.B1 & 0.7082 & & & \\
\hline Stra.B2 & 0.7727 & & & \\
\hline Stra.B3 & 0.7856 & & & \\
\hline Stra.B4 & 0.6089 & & & \\
\hline Stra.B5 & 0.6542 & & & \\
\hline Satisfaction & & 1.0000 & 1.0000 & 1.0000 \\
\hline Satis & 1.0000 & & & \\
\hline
\end{tabular}

Table 3: Discriminant Validity: Correlations and AVE's square root

\begin{tabular}{|c|c|c|c|c|}
\hline & ECON.B & TECHNO.B & STRA.B & SATISFA \\
\hline Eco.B1 & 0.8643 & 0.4202 & 0.3466 & 0.3765 \\
\hline Eco.B2 & 0.9000 & 0.6604 & 0.3663 & 0.4441 \\
\hline Tech.B1 & 0.5091 & 0.8863 & 0.4848 & 0.3828 \\
\hline Tech.B2 & 0.6172 & 0.9466 & 0.5143 & 0.5498 \\
\hline Stra.B1 & 0.2292 & 0.3939 & 0.7082 & 0.2872 \\
\hline Stra.B2 & 0.2688 & 0.3959 & 0.7727 & 0.4540 \\
\hline Stra.B3 & 0.3606 & 0.5119 & 0.7856 & 0.4493 \\
\hline Stra.B4 & 0.3009 & 0.3264 & 0.6089 & 0.2914 \\
\hline Stra.B5 & 0.2711 & 0.2856 & 0.6542 & 0.4186 \\
\hline Satis & 0.4672 & 0.5220 & 0.5491 & 1.0000 \\
\hline \multicolumn{5}{|c|}{ Latent Variables' Correlations } \\
\hline & ECON.B & TECHNO.B & STRA.B & SATISFA \\
\hline ECON.B & 0.7785 & & & \\
\hline TECHNO.B & 0.6214 & 0.91695 & & \\
\hline STRA.B & 0.4043 & 0.5447 & 0.7091 & \\
\hline SATISFA & 0.4672 & 0.5220 & 0.5491 & 1.0000 \\
\hline
\end{tabular}


Table 4: Factor loadings, factor weights and T statistic

\begin{tabular}{|l|r|r|r|r|}
\hline & \multicolumn{1}{|c|}{ VIF } & \multicolumn{1}{c|}{ Loadings } & \multicolumn{1}{c|}{ Weights } & \multicolumn{1}{c|}{$\mathrm{T}$} \\
\hline TM1 & 1.694 & 0.7977 & 0.5508 & 0.8359 \\
\hline TM2 & 1.717 & 0.8541 & 0.6780 & $1.2738^{*}$ \\
\hline TM3 & 1.024 & 0.0424 & -0.4366 & 0.6119 \\
\hline Degree1 & 2.319 & 0.6771 & 0.1801 & 0.6888 \\
\hline Degree2 & 2.810 & 0.2479 & -0.1717 & 0.5531 \\
\hline Degree3 & 2.485 & 0.2691 & -0.0839 & 0.2874 \\
\hline Degree4 & 2.127 & 0.7507 & 0.3537 & $1.0947 *$ \\
\hline Degree6 & 2.297 & 0.7396 & 0.2238 & 0.7072 \\
\hline Degree7 & 2.488 & 0.5451 & -0.0669 & 0.2142 \\
\hline Degree8 & 2.855 & 0.7878 & 0.3912 & $1.4765 * *$ \\
\hline Degree9 & 1.374 & 0.6998 & 0.1589 & 0.5412 \\
\hline Degree10 & 1.753 & 0.6554 & 0.1938 & 0.6903 \\
\hline Degree11 & 1.830 & 0.3643 & 0.0062 & 0.0227 \\
\hline Prov1 & 1.012 & 0.3515 & 0.2237 & 0.5084 \\
\hline Prov2 & 1.430 & 0.9579 & 0.8132 & $1.3629 * *$ \\
\hline Prov3 & 1.416 & 0.6651 & 0.2141 & 0.3705 \\
\hline * p $<0.3 * * ;<0.2$ & & & \\
\hline
\end{tabular}

Table 5: Structural Model Assessment

\begin{tabular}{|c|c|c|c|c|c|c|}
\hline & $\mathrm{B}$ & $\begin{array}{c}\mathrm{T} \\
\text { (boostrap) }\end{array}$ & $\begin{array}{c}\text { Variance } \\
\text { Explained }\end{array}$ & $\mathrm{R}^{2}$ & $\mathrm{Q}^{2}$ & $\begin{array}{l}\text { Hypothesis } \\
\text { acceptance }\end{array}$ \\
\hline ECO.B & & & & 0.102 & 0.0718 & \\
\hline TECHNO.B & & & & 0.140 & 0.1087 & \\
\hline STRA.B & & & & 0.116 & 0.0556 & \\
\hline SATISFA & & & & 0.395 & 0.3968 & \\
\hline H1a: Prov $\rightarrow$ Eco.B & 0.1690 & 1.5719’’ & 3.4239 & & & $X$ \\
\hline H1b: Prov $\rightarrow$ Tec.B & 0.0638 & 0.5949 & & & & \\
\hline H1c: Prov $\rightarrow$ Stra.B & -0.0500 & 0.4182 & & & & \\
\hline H2a: Degree $\rightarrow$ Eco.B & 0.2468 & $2.2988 *$ & 6.5747 & & & $\mathrm{X}$ \\
\hline H2b: Degree $\rightarrow$ Tec.B & 0.3606 & $3.3723 * * *$ & 13.2376 & & & $\mathrm{X}$ \\
\hline H2c: Degree $\rightarrow$ Stra.B & 0.2822 & $2.4609 * *$ & 8.1442 & & & $\mathrm{X}$ \\
\hline H3a: $\mathrm{SM} \rightarrow$ Eco.B & -0.0517 & 0.3266 & & & & \\
\hline H3b: SM $\rightarrow$ Tec.B & -0.0308 & 0.2407 & & & & \\
\hline H3c: SM $\rightarrow$ Stra.B & 0.1753 & 1.0929', & 3.4341 & & & $\mathrm{X}$ \\
\hline H4a: Eco.B $\rightarrow$ Satis & 0.1942 & $1.6803^{*}$ & 9.0730 & & & $\mathrm{X}$ \\
\hline H4b: Tec.B $\rightarrow$ Satis & 0.2063 & $1.6441^{*}$ & 10.7688 & & & $\mathrm{X}$ \\
\hline H4c: Stra.B $\rightarrow$ Satis & 0.3582 & $3.0818 * *$ & 19.6687 & & & $\mathrm{X}$ \\
\hline
\end{tabular}

'p<0.20; " $\mathrm{p}<0.10$; * $\mathrm{p}<0.05$; ** $\mathrm{p}<0.01$; *** $\mathrm{p}<0.001$ 
Figure 1: Proposed Model (part a and part b)

a)
Providers
Economic B.

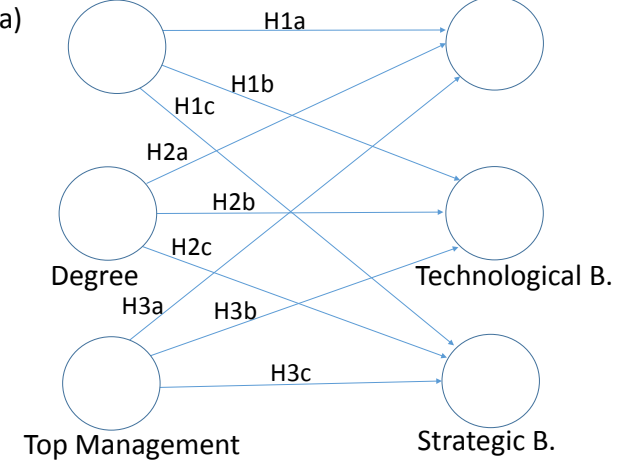

b)
Providers
Economic B.
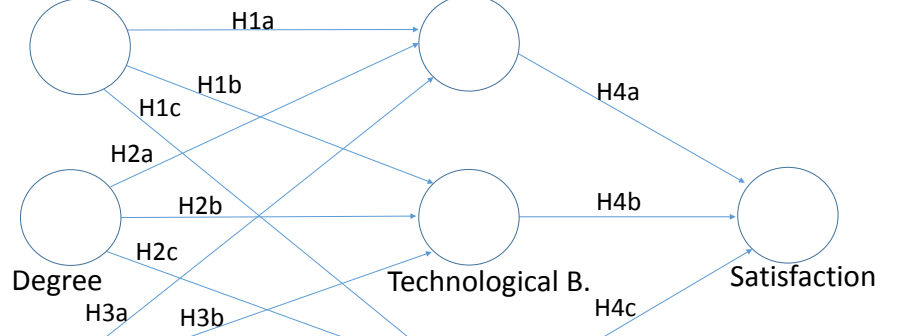

$\mathrm{H} 3 \mathrm{c}$

Top Management

Strategic B.

Figure 2: Degree of IS Outsourcing

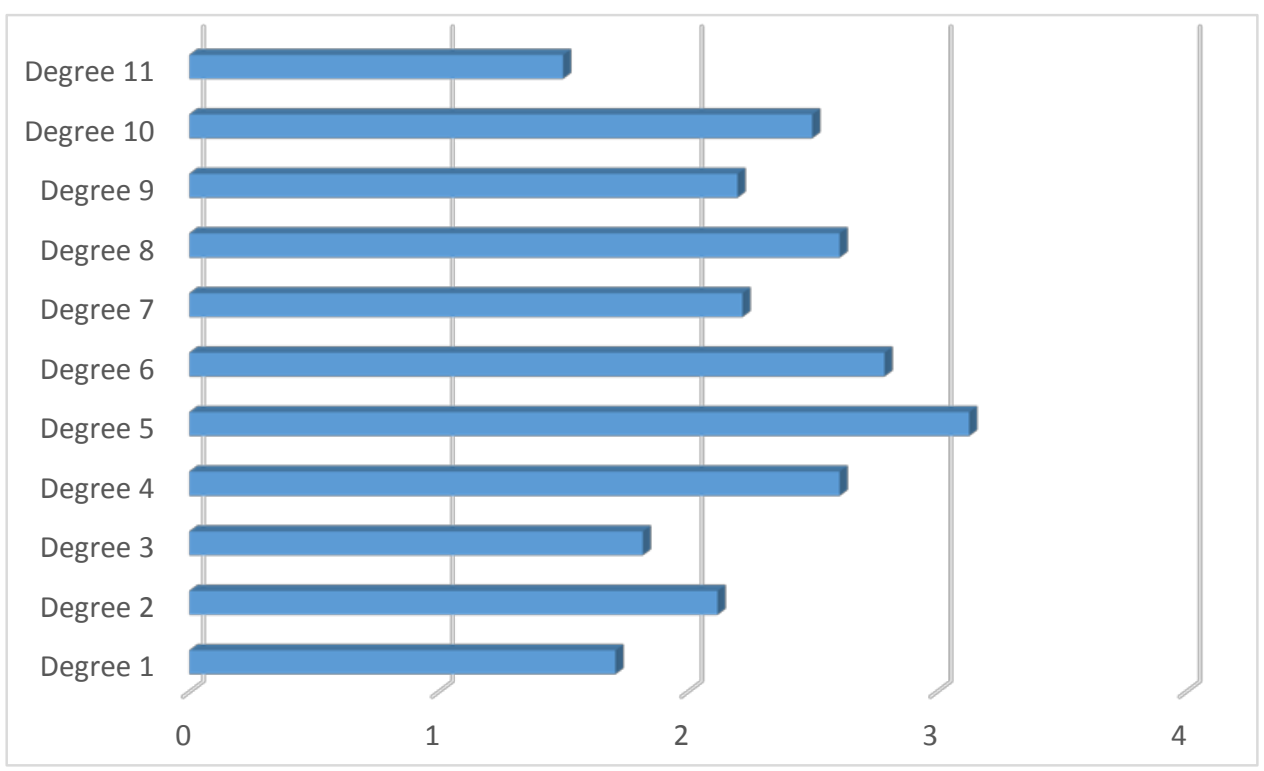


Figure 3: Relationship with Providers, Top Management’s role, Perceived Benefits and Satisfaction

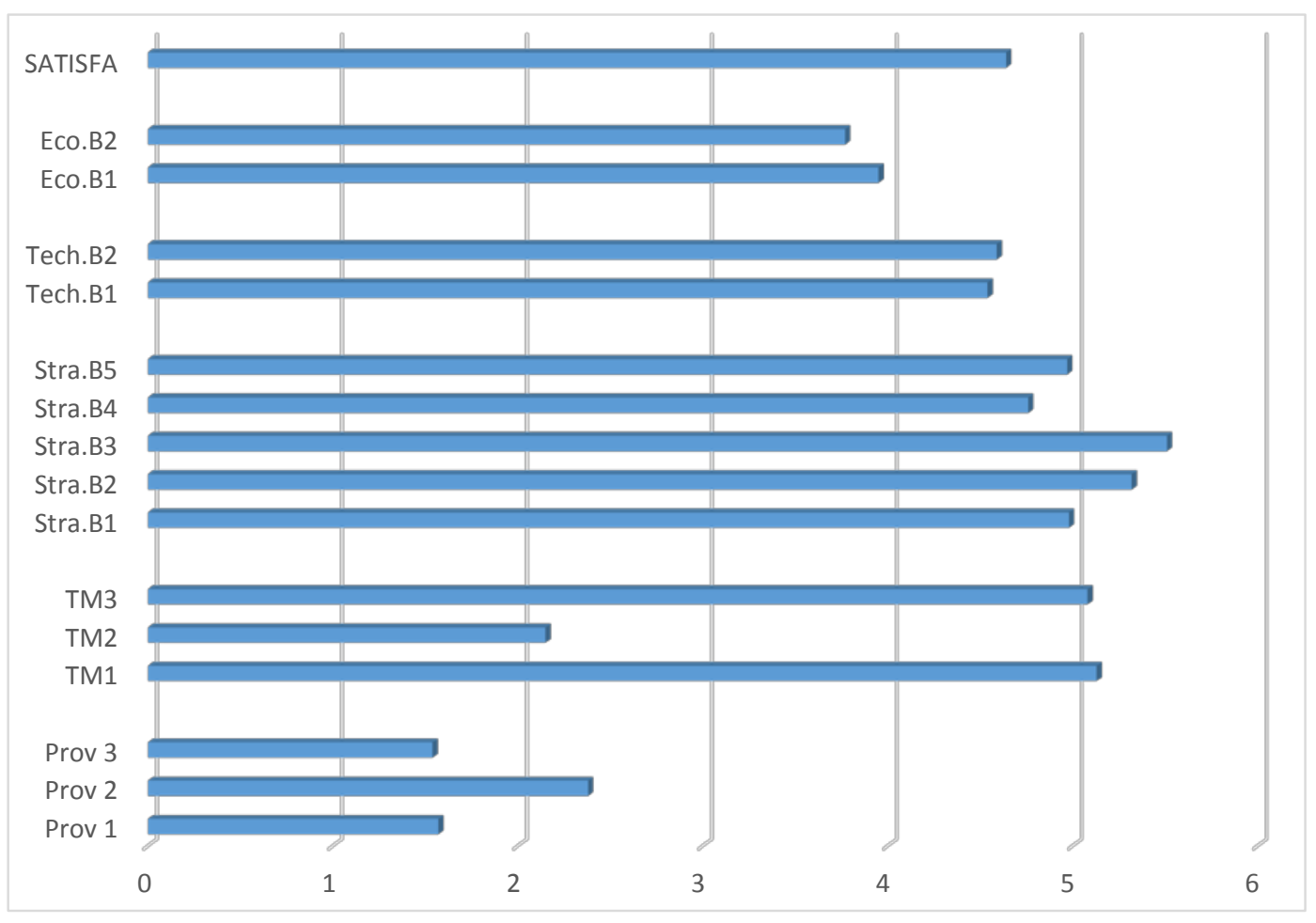

Figure 4: Complete model proposed vs. its simplified version
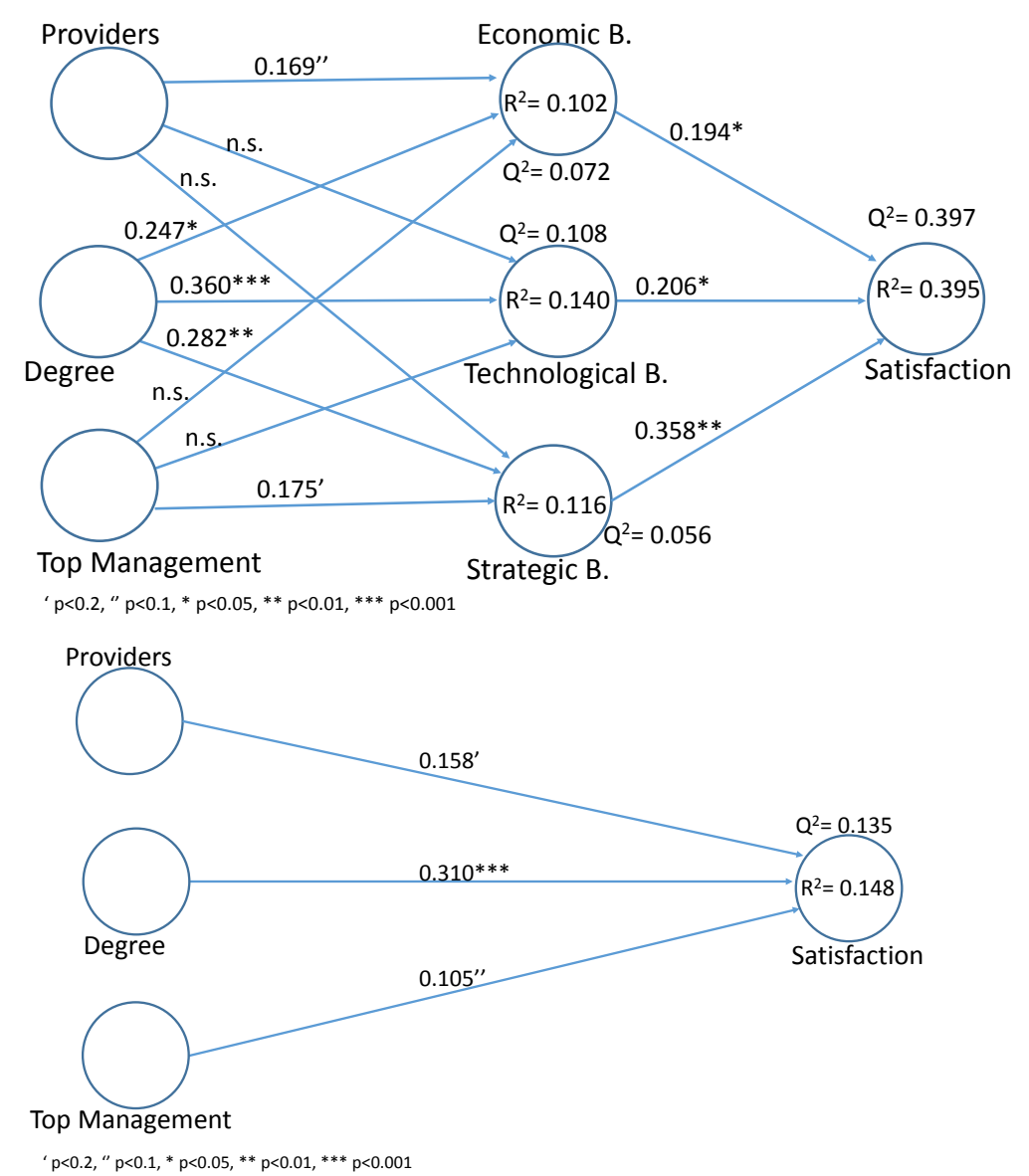